\title{
Retinyl Palmitate
}

National Cancer Institute

\section{Source}

National Cancer Institute. Retinyl Palmitate. NCI Thesaurus. Code C1217.

A naturally-occurring phenyl analogue of retinol (vitamin A) with potential antineoplastic and chemopreventive activities. As the most common form of vitamin A taken for dietary supplementation, retinyl palmitate binds to and activates retinoid receptors, thereby inducing cell differentiation and decreasing cell proliferation. This agent also inhibits carcinogen-induced neoplastic transformation, induces apoptosis in some cancer cell types, and exhibits immunomodulatory properties. ( $\mathrm{NCl} 04)$ 